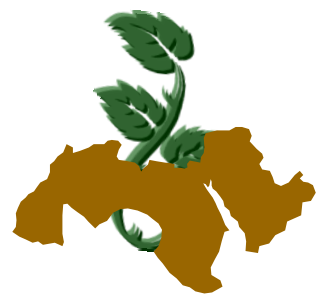

\title{
MORPHOLOGICAL AND MOLECULAR CHARACTERIZATION OF ECTOMYCORRHIZAL FUNGI ISOLATED FROM EGYPTIAN ENVIRONMENT
}

\author{
Mona, S. Zayed ${ }^{1,2}$; Sh. Selim ${ }^{1,2}$; Wedad, E. Eweeda', 2; M. K. Ali ${ }^{3}$ \\ and A. Hazem ${ }^{1}$
}

1. Microbiology Dept.. Fac. Agric., Ain Shams Univ., Shobra El-Kheima, Cairo

2. Unit of Biofertiliz., Fac. Agric., Ain Shams Univ., Shobra El-Kheima, Cairo

3. Plant Pathology Dept., Fac. Agric., Ain Shams Univ., Shobra El-Kheima, Cairo

Keywords: Isolation, Sporocarpes, Identification, Ectomycorrhizae, Growth parameters of Pinus

\begin{abstract}
In a trial to isolate and identify ectomycorrhizal fungi for the first time in Egypt 13 sporocarpes associated with rang of plants grown on Egyptian soils were collected, to be used for this purpose. Fungal isolates were obtained from collected sporocarpes and tested for ectomycorrhiza formation with Bauhinia sp. and Pinus seedlings. The paper sandwich technique was used for simultaneous inoculation of root apices Bauhinia to produce synchronously developing ectomycorrhizas. Typical ectomycorrhizal roots were obtained within 14 days after inoculation with the collected strains. The isolates tested for ectomycorrhiza formation with Pinus sp. to ensure their identity by formation of distinct root characteristics on this host. Root colonization levels varied markedly among the tested fungal strains with respect to growth enhancement and NPK uptake of Pinus shoots and roots.
\end{abstract}

\section{INTRODUCTION}

Ectomycorrhizae (ECM) represents a complex interaction between fungi and plant roots. Fungi forming ECM are diverse in morphological and physiological characteristics (Allen et al 1995 and Molina et al 1992) and are mostly belonging to Basidiomycota, Ascomycota, Zygomycota or one specie of imperfect fungi (Read, 1991 and Molina et al 1992).
They are functionally important in temperate forest ecosystems for plant nutrient and water uptake as well as protection from root pathogens (Smith \& Read, 1997).

ECM fungi are usually isolated from fruiting body tissue, sexual spores, and bulky substrates such as rhizomorphs, mycelial cords, sclerotia and fungal sheath. Fruiting bodies provide the majority of diagnostic characters used for ECM fungi identification, while non fruiting isolates derived from vegetative materials require more taxonomic and culture experience. Isolation is more easily achieved from bulky fruiting bodies than from other structures (Hutchinson, 1991 and True \& Agerer, 1990).

Ectomycorrhizal inoculation is particularly important because native soil population of this group may be low in both afforested and disturbed areas (Perry et al 1995) or incompatible with the introduced species. In pouch cases, nursery inoculations with selected ectomycorrhizal fungi adapted to the ecological conditions of the planting area may by necessary (Marx, 1980).

This study aimed to isolate and identify ECM isolates fungi collected from different sites in Egypt along with evaluation the infectiveness and effectiveness on Pinus plants.

\section{MATERIALS AND METHODS}

\section{Sources of Sporocarpes}

Young sporocarpes free of rot and insect damage and fully matured Sporocarpes were collected from Macharium tipu, Doranta, Grape, Citrus and 
weeds. The sporocarpes were placed into waxed paper bag and kept in low temperature in the refrigerator until examination.

\section{Seeds of host plants}

Seeds of Bauhinia and Pinus were kindly obtained from forestry and woody tree Department, Horticulture research Institute, ARC. Giza.

\section{Identification of ECM fungi}

\subsection{Making spore prints}

In the case of mushrooms, the stem was cut from a mature sporocarpes, the cap were placed over a card and covered with waxed paper, caps were laid flat over the card to obtain a spore print. After a period of one hour to overnight, the white or colored spores deposit on the paper was obtained. Spore prints were used for microscopic and macroscopic examination according to Brundrett et al (1996).

\subsection{Sporocarpes and spores characteristics}

Macroscopic and microscopic examinations of the fruiting bodies or spores morphology were based on following characteristics (Cap-GillsStep-Universal veil- Partial veil- Spore print color, spore size, spore shape, spore well structure and ornamentation) as described by Brundrett $\boldsymbol{e t}$ al (1996) and Agerer, (1991).

\section{Isolation of ECM fungi from Sporocarpes}

Adhering debris were brushed especially from the step base. For the mushroom, a shallow slit (1$2 \mathrm{~mm}$ ) was cut across the middle of the cap surface and along the length of a side of the step.

To expose interior tissue, the sporocarpes were gently pulled apart along the initial shallow cuts, using fingertip pressure. Quickly the exposed interior surface for areas of tissue free from contact with obvious contaminating sources was scanned. A small amount of tissue was removed with a fine forceps and placed on MMN agar medium (Marx, 1969) contained Malt extract $3 \mathrm{~g} \&$ d-glucose $10 \mathrm{~g} \&(\mathrm{NH} 4)_{2} \mathrm{HPO}_{4}, 25 \mathrm{~g} \& \mathrm{KH}_{2} \mathrm{PO}_{4}, 5 \& \mathrm{MgSO}_{4}$ , $15 \& \mathrm{CaCl}_{2} \quad .05 \mathrm{~g} \& \mathrm{FeCl}_{3} \quad 1 \%$ solution $(1,2 \mathrm{ml})$ \& thiamin $\mathrm{HCl} 100$ ug \& distilled $\mathrm{H}_{2} \mathrm{O} 1000 \mathrm{ml}$ $\& \mathrm{pH} \mathrm{5,8}$ in a Petri dish. After3 to 4 days observation for initial fungus growth and contamination was examined under a stereomicroscope. Fungi which are easily isolated and grow well in culture produce visible mycelial growth 4 to 7 days after isolation. Other fungi may take 2 to 6 weeks to show any sign of growth (the tissue cultures are usually incubated at 25 to $28{ }^{\circ} \mathrm{C}$ ). After ectomycorrhizal fungus established on the medium with no visible contaminants, mycelia from the developed colony edge were aseptically transferred with a needle onto fresh MMN medium to set up a stock culture.

\section{Infection test}

Healthy, uniformly sized seeds of Bauhinia sp host plants were selected, and surface sterilized with $5 \%$ sodium hypoclorite $(\mathrm{NaOCl})$ for $20 \mathrm{~min}$. Sterilized seeds were washed with three changes of sterile water, and were individually placed on agar in plates for germination and checked for contaminating microbes.

Petri dishes (140-20mm) were filled with 30 $\mathrm{ml}$ of complete nutrient agar based on solution for plant nutrient (Brundrett et al 1996) culture that maximizes mycorrhizal development

On Bauhinia seedling. The agar media was overlain with cellophane disks that have been washed, autoclaved before use. Discs of hyphal plug ( $5 \mathrm{~mm}$ in diameter) was taken by cork borer from the edge of 14 day old colonies of ECM fungi growing in agar media. These plugs were placed approximately $1.5 \mathrm{~cm}$ apart in 2 rows in the center of petri dish. Plates were incubated at $25-28{ }^{\circ} \mathrm{C}$ in the dark, until sufficient hyphal growth has occurred. Axenically germinating seeds with a short radical were placed in a row $1-2 \mathrm{~cm}$ above the growing hyphae. The plates were incubated on a slant, so the seedling roots grow toward the fungus and adhere to the cellophane surface. Plates with fungi and seedling were incubated at $25{ }^{\circ} \mathrm{C}$ with the presence of adequate light for seedling growth (Burgess et al 1996).

On Pinus seedlings. A pot experiment was conducted in the Unit of Biofertelizers greenhouse, Faculty of Agriculture, Ain shams University. Pinus plants infection techniques were made to test the potent of ECM strains. For this purpose polyethylene bags filled with $500 \mathrm{~g}$ of clay and sand soil (2:1) and inoculated with $10 \mathrm{~g}$ of a colonized ECM inoculum (each strain separately). Seeds of Pinus were planted and then watered when necessary. Four replicates were used for each treatment. After 3 months from planting under greenhouse conditions, the plants were collected to observation and photographs. 


\section{Evaluation infectiveness and effectiveness of ECM fungal strains on Pinus seedlings}

\section{a) Preparation of ECM fungal inoculum}

A 10 disk $(0,5 \mathrm{~cm})$ of the 4 weeks old colony of each one of ECM fungi isolates were aseptically transfer into bottles containing of 100 gram of cooked and sterilized wheat grain. Bottles were incubated at $25^{\circ} \mathrm{C}$ for 2 months and mixed well periodically.

\section{b) Experimental technique}

The enffectiveness and effectiveness of the 4 ECM strains on growth and N, P, K uptake of Pinus seedling were evaluated under greenhouse conditions. The soil samples were mixed sieved and sterilized by autoclaving, and placed into polyethylene bag $(10 \times 20 \mathrm{~cm})$ and packed at rat of $1 \mathrm{~kg}$. The pages were inoculated with $10 \mathrm{~g} \mathrm{ECM}$ inoculum before seeds were planted. The developed seedlings were watered once weekly.

\section{d) Parameter measured}

Five months old seedling were carefully collected to record shoot and root length $(\mathrm{cm} / \mathrm{plant})$, shoot and root dry weight (g/plant), dichotomous/plant.

Total nitrogen, phosphorus and potassium uptake of Pinus seedlings shoots and roots were determined according to the methods described by Jackson, (1973).

7) Determination of similarity index of identified ECM fungi using the Inter-Simple Sequence repeat Polymerase Chain Reaction (ISSR-PCR)

For this purpose DNA were extracted from axenic mycelia of all tested isolates using the methods of Jin et al (2004). The inter-simple sequence repeat PCR reactions (ISSR- PSR) were performed using the degenerate primers 844A (CT8AC); HB11 (GT) 6CC; HB9 (GT) 6GG; HB12 (CAC) 3GC; HB13 (GAG) 3GC; HB14 (CTC)3GC; HB15 (GTG)3GC. DNA amplification was performed in a model 2400 Perkin-Elmer DNA thermal cycler. PCR reactions were performed in a $25 \mu$ l template DNA solution containing approximately $100 \mathrm{ng}$ genomic DNA $200 \mu \mathrm{l}$ of dATP, dTTP, dCTP, and dGTP,50 mM KCl, $2.0 \mathrm{mM} \mathrm{MgCl}_{2}, 10 \mathrm{mM}$ Tris - $\mathrm{HCl}$ (pH 9.0), $0.1 \%$ Triton X -100 and 1.5 unit Taq DNA polymerase (Bioron- Germany). The PCR amplification prod- ucts were separated by electrophoresis in $1.8 \%$ agarose gel in $0.5 \mathrm{x}$ TBE (Tris-boric acid-EDTA) buffer at low voltage over night. After electrophoresis gels were stained with ethidium bromide and photographed on a UV transilluminator. The DNA size marker used for electrophoresis was the 100bp plus Ladder (GIBCO-BRL, NY) (Zhou $\boldsymbol{e t}$ al 2001).

\section{RESULTS}

\section{Isolation and identification of EMC fungi}

Thirteen fungal isolates were obtained from fruiting bodies collected from weeds, Citrus, Grapes, Doranta and Macharium tipu plants, respectively

Based on macroscopic examination of cap, cap surface, stip surface, gill attachment, ring, cap cuticle and cortina Step, Universal veil, partial veil, spore print color, spore wall and spore shape as characteristics proposed by Brundrett $\boldsymbol{e t}$ al (1996) for ECM identification. Four out of the Thirteen sporocarpes were found to belong to ectomycorrhizal genera Leccinum sp., Hebloma sp., Amanita sp. and Cortinus sp. (See Figs. 1-4). The characteristics and results are given in Table (1).

\section{Confirmatory test for ectomycorrhizal for-} mation by identified fungi.

The four identified strains were tested for their ability to form association with Bauhinia and $P i$ nus roots (See Fig.5 a\&b and Fig. 6).

\section{Bauhinia}

Bauhinia plantlets grown on sterile MMN medium and inoculated with either of the 4 tested. fungi, within 2 weeks. The hyphae were sparse and the mantel was unrecognized in the first 4.5 days. But the hyphae were completely surrounded the main root and the mantel was developed and recognized at day 14. Microscopic examination of the roots showed totally enveloped root system and the newly emerging lateral roots were completely enveloped by the fungal hyphae which form distinct mantel (Fig. 5 a, b)

\section{Pinus}

Roots of Pinus seedlings showed the distinguished characteristics known for ectomycorrhizal formation. Hence, plants harvested after 3 months of inoculation showed a distinct dichotomously branched roots (see Fig. 6). 
Fig 1. Fruiting body (mature stage Leccinum sp. (F8).

Fig 2. Fruiting bodies Hebloma sp. (F9) a) Bottom stage, b) mature stage, c) spore print, d) primordia on plat.

Fig 3. Fruiting bodies Amanita sp. (F10) a) bottom stage; b) mature stage, c) spore print, d) primordia on plat.

Fig 4. Fruiting bodies Cortinus sp. (F11) a, b) bottom stage; c) mature stage, d) spore print.

Fig 5. Ectomycorrhizal synthesis on roots of Bauhinia grown in sterile MMN medium.

Fig 6. Ectomycorrhizal synthesis on roots of Pinus

Fig 7. a,b) Characteristics of Ectomycorrhizal roots on Pinus. 
Table 1. Characteristics of ECM fungi isolated from sporocarpes

\begin{tabular}{|c|c|c|c|c|}
\hline Isolate & $\mathbf{F}(\mathbf{8})$ & $\mathbf{F}(9)$ & $F(10)$ & $\mathbf{F}(11)$ \\
\hline Host & Macharium tinu & Weeds & Weeds & Weeds \\
\hline Spore wall & Smooth & Smooth & Smooth & Smooth \\
\hline Spore shape & Fusoid elongate & Fusoid & Global to ellipsoid & Global \\
\hline Cap surface & Smooth sponge & Smooth & Smooth & Smooth \\
\hline Mushroom cap & Tubular & With gills & With gills & With gills \\
\hline Veil & Partial veil & Absent & Partial veil & Partial veil \\
\hline Stip surface & With dots & smooth & smooth & smooth \\
\hline Stip long & Long & Short & Long & Long \\
\hline Gill attachment & Pores & Free & Free & Free \\
\hline Ring & Absent & Absent & Present & Present \\
\hline Cap cuticle & - & Filamentous & Filamentous & Filamentous \\
\hline Cortina & Absent & Absent & Absent & Present \\
\hline Genus & Leccinum sp. & Hebloma sp. & Amanita sp. & Cortinus sp. \\
\hline Family & Boletaceae & Cortinariaceae & Amanitaceae & Cortinariaceae \\
\hline
\end{tabular}

\section{ISSR analysis}

Highly purified DNA extracts of the four ECM strains were used as templates for ISSR-PCR. Data revealed that no amplified fragments were observed in any of the negative controls (PCR mixture without any DNA templates), which indicates that reaction mixtures were free from any contamination DNA. Data in Table (2) showed that the number of amplified fragments differed with different primers, which is expected. On the other hand, the number and sizes of amplified fragments differed from one strain to another for the same primer. This is clear since as they differed in their DNA sequences. Data in Table (3) showed that a total number of 70 amplified fragments were obtained using the seven primers used. In addition, $40,48.6,58.8$ and $57.1 \%$ of the 70 fragments were amplified from the DNA of the four ECM strains (F9, F11, F8 and F10), respectively. Results in Table (4) showed that out of the 70 fragments, 16 unique fragments distributed as follows: 4, 2, 5, and 5 for F9, F11, F8 and F10 ECM strains, respectively, were found. Results in Table (5) revealed that the similarity between the DNA of the four ECM strains in this investigation ranged from
49.3\% to 64.5\%. Results in Fig. (8) showed the phylogenetic tree of the four tested strains. The first cluster included strains F9 \& F11 with similarity of $64.5 \%$. While, strains F11 \& F8 laid in the second cluster with $61.3 \%$ similarity.

\section{Application of ECM strains on Pinus growth parameter.}

After 5 months of cultivation, growth of Pinus seedlings were evaluated as affected by inoculation with 4 strains of ECM. Data recorded in Table (6) show that inoculation with ECM gave the higher growth performance of shoot, root length $(\mathrm{cm} /$ plant) and shoot, root dry weight (g/plant) compared with uninoculated (control) plants (Fig. $7 \mathbf{a \& b}$ ). Inoculating the four ECM strains onto Pinus seedling showed that all ECM strains were able to form mycorrhizal dichotomous roots. However there were differences among in this ECM strains in their ability to being $64.17,43$, 37.5 and 26 dichotomous root/plant with stains F10, F11, F9 and F8, respectively. The maximum Pinus root colonization reached to 64.17 and 43 mycorrhizal dichotomous roots/plant with strains F10 and F11, respectively, (Table 6). 
Table 2. ISSR analysis of seven ectomycorrhizal fungi isolates shows the DNA polymorphisms produced using 7 primers

\begin{tabular}{|c|c|c|c|c|c|}
\hline \multirow[b]{2}{*}{ NAF } & \multirow{2}{*}{$\begin{array}{l}\text { MW } \\
\text { (bp) }\end{array}$} & \multicolumn{4}{|c|}{ Ectomycorrhizal fungi isolates } \\
\hline & & F9 & F11 & F8 & F10 \\
\hline \multicolumn{6}{|c|}{ 8448b Primer } \\
\hline 1 & 1.884 & 0 & 0 & 1 & 0 \\
\hline 2 & 1.614 & 0 & 1 & 0 & 0 \\
\hline 3 & 0.991 & 0 & 0 & 1 & 0 \\
\hline 4 & 0.743 & 1 & 1 & 1 & 1 \\
\hline 5 & 0.583 & 1 & 1 & 1 & 1 \\
\hline 6 & 0.466 & 0 & 0 & 1 & 0 \\
\hline 7 & 0.413 & 1 & 1 & 0 & 0 \\
\hline 8 & 0.377 & 0 & 0 & 1 & 0 \\
\hline 9 & 0.311 & 0 & 1 & 0 & 0 \\
\hline 10 & 0.26 & 1 & 1 & 1 & 0 \\
\hline 11 & 0.181 & 1 & 1 & 1 & 0 \\
\hline \multicolumn{6}{|c|}{ HB-09 Primer } \\
\hline 12 & 3.396 & 1 & 0 & 0 & 0 \\
\hline 13 & 2.646 & 1 & 0 & 0 & 0 \\
\hline 14 & 1.94 & 1 & 1 & 1 & 1 \\
\hline 15 & 1.206 & 0 & 0 & 0 & 0 \\
\hline 16 & 1.097 & 1 & 1 & 1 & 1 \\
\hline 17 & 0.848 & 1 & 1 & 1 & 1 \\
\hline 18 & 0.547 & 0 & 1 & 1 & 1 \\
\hline \multicolumn{6}{|c|}{ HB-11 Primer } \\
\hline 19 & 1.428 & 0 & 0 & 1 & 0 \\
\hline 20 & 1.206 & 0 & 0 & 0 & 0 \\
\hline 21 & 1.114 & 0 & 0 & 1 & 0 \\
\hline 22 & 0.97 & 0 & 0 & 1 & 0 \\
\hline 23 & 0.732 & 1 & 1 & 1 & 0 \\
\hline 24 & 0.607 & 1 & 1 & 1 & 1 \\
\hline 25 & 0.518 & 1 & 1 & 0 & 0 \\
\hline 26 & 0.421 & 1 & 1 & 1 & 1 \\
\hline 27 & 0.365 & 0 & 0 & 1 & 0 \\
\hline \multicolumn{6}{|c|}{ HB-12 Primer } \\
\hline 28 & 2.093 & 1 & 1 & 1 & 1 \\
\hline 29 & 1.238 & 1 & 1 & 1 & 1 \\
\hline 30 & 0.839 & 0 & 1 & 0 & 1 \\
\hline 31 & 0.553 & 0 & 0 & 0 & 1 \\
\hline 32 & 0.346 & 1 & 1 & 1 & 1 \\
\hline \multicolumn{6}{|c|}{ HB-13 Primer } \\
\hline 33 & 1.939 & 0 & 0 & 1 & 1 \\
\hline 34 & 1.594 & 0 & 1 & 1 & 1 \\
\hline 35 & 1.467 & 1 & 0 & 0 & 1 \\
\hline 36 & 1.341 & 0 & 1 & 0 & 1 \\
\hline 37 & 1.228 & 1 & 0 & 1 & 1 \\
\hline 38 & 1.158 & 0 & 0 & 0 & 0 \\
\hline 39 & 1.079 & 1 & 1 & 0 & 0 \\
\hline 40 & 0.963 & 0 & 1 & 1 & 1 \\
\hline 41 & 0.868 & 1 & 0 & 0 & 1 \\
\hline 42 & 0.795 & 0 & 1 & 1 & 0 \\
\hline
\end{tabular}

Table 2. Continue.

\begin{tabular}{|c|c|c|c|c|c|}
\hline \multirow[b]{2}{*}{ NAF } & \multirow{2}{*}{$\begin{array}{l}\text { MW } \\
\text { (bp) }\end{array}$} & \multicolumn{4}{|c|}{ Ectomycorrhizal fungi isolates } \\
\hline & & F9 & F11 & F8 & F10 \\
\hline 43 & 0.699 & 0 & 0 & 0 & 1 \\
\hline 44 & 0.6 & 0 & 0 & 0 & 1 \\
\hline \multicolumn{6}{|c|}{ HB-14 Primer } \\
\hline 45 & 1.939 & 0 & 0 & 1 & 1 \\
\hline 46 & 1.594 & 0 & 1 & 1 & 1 \\
\hline 47 & 1.467 & 1 & 0 & 0 & 1 \\
\hline 48 & 1.341 & 0 & 1 & 0 & 1 \\
\hline 49 & 1.228 & 1 & 0 & 1 & 1 \\
\hline 50 & 1.158 & 0 & 0 & 0 & 0 \\
\hline 51 & 1.079 & 1 & 1 & 0 & 0 \\
\hline 52 & 0.963 & 0 & 1 & 1 & 1 \\
\hline 53 & 0.868 & 1 & 0 & 0 & 1 \\
\hline 54 & 0.795 & 0 & 1 & 1 & 0 \\
\hline 55 & 0.699 & 0 & 0 & 0 & 1 \\
\hline 56 & 0.6 & 0 & 0 & 0 & 1 \\
\hline \multicolumn{6}{|c|}{ HB-15 Primer } \\
\hline 57 & 1.974 & 0 & 0 & 1 & 0 \\
\hline 58 & 1.747 & 0 & 0 & 1 & 0 \\
\hline 59 & 1.576 & 0 & 0 & 0 & 1 \\
\hline 60 & 1.488 & 0 & 0 & 1 & 0 \\
\hline 61 & 1.319 & 1 & 1 & 0 & 1 \\
\hline 62 & 1.235 & 1 & 1 & 1 & 0 \\
\hline 63 & 1.04 & 0 & 1 & 0 & 1 \\
\hline 64 & 0.939 & 0 & 0 & 1 & 0 \\
\hline 65 & 0.846 & 1 & 1 & 1 & 1 \\
\hline 66 & 0.713 & 0 & 0 & 1 & 1 \\
\hline 67 & 0.642 & 0 & 0 & 0 & 1 \\
\hline 68 & 0.514 & 0 & 0 & 1 & 1 \\
\hline 69 & 0.447 & 0 & 0 & 0 & 1 \\
\hline 70 & 0.394 & 0 & 1 & 1 & 1 \\
\hline
\end{tabular}

Table 3. Total amplified fragments of seven ectomycorrhizal fungi isolates based on ISSR analysis using 7 primers.

\begin{tabular}{|cccccc|}
\hline & & \multicolumn{4}{c|}{ Ectomycorrhizal fungi isolates } \\
\cline { 3 - 6 } NAF & TAF & F9 & F11 & F8 & F10 \\
\hline 8448b & 11 & 5 & 7 & 8 & 2 \\
HB-09 & 7 & 5 & 4 & 4 & 4 \\
HB-11 & 9 & 4 & 4 & 7 & 2 \\
HB-12 & 5 & 3 & 4 & 3 & 5 \\
HB-13 & 12 & 4 & 5 & 6 & 11 \\
HB-14 & 12 & 4 & 5 & 4 & 7 \\
HB-15 & 14 & 3 & 5 & 9 & 9 \\
\hline Total No. & 70 & 28 & 34 & 41 & 40 \\
\hline$\%$ & 100 & 40 & 48.6 & 58.8 & 57.1 \\
\hline
\end{tabular}

NAF: Number of amplified fragments.

TAF: Total amplified fragments. 
Table 4. Unique fragments of seven ectomycorrhizal fungi isolates based on ISSR analysis using 7 primers.

\begin{tabular}{|cccccc|}
\hline \multirow{2}{*}{ NAF } & \multirow{5}{*}{ TAF } & \multicolumn{5}{c|}{ Ectomycorrhizal fungi isolates } \\
\cline { 3 - 6 } & & F9 & F11 & F8 & F10 \\
\hline 8448b & 11 & 0 & 1 & 4 & 2 \\
HB-09 & 7 & 2 & 0 & 0 & 2 \\
HB-11 & 9 & 0 & 0 & 1 & 0 \\
HB-12 & 5 & 0 & 0 & 0 & 1 \\
HB-13 & 12 & 1 & 0 & 0 & 0 \\
HB-14 & 12 & 0 & 1 & 0 & 0 \\
HB-15 & 14 & 1 & 0 & 0 & 1 \\
\hline Total & 70 & 4 & 2 & 5 & 5 \\
\hline
\end{tabular}

NAF: Number of amplified fragments.

TAF: Total amplified fragments.

Table 5. Similarity between four identified ECM fungi based on ISSR-PCR analysis using Dice Measure

\begin{tabular}{|ccccc|}
\hline \multirow{2}{*}{$\begin{array}{c}\text { ECM } \\
\text { isolates }\end{array}$} & \multicolumn{4}{c|}{ \%of similarity between the ECM strains } \\
\cline { 2 - 5 } & F9 & F11 & F8 & F10 \\
\hline F 9 & 100 & & & \\
F11 & 64.5 & 100 & & \\
F8 & 49.3 & 61.3 & 100 & \\
F10 & 52.9 & 59.5 & 56.8 & 100 \\
\hline
\end{tabular}
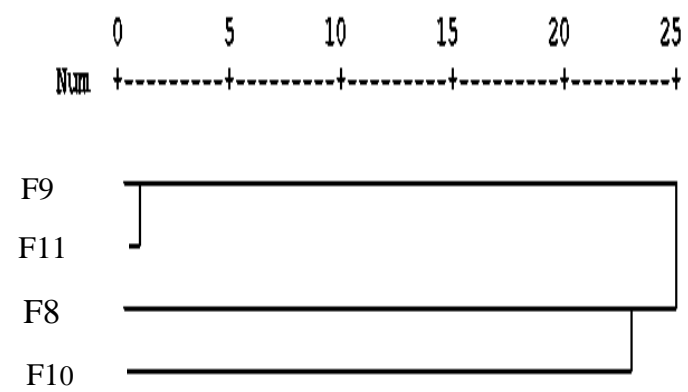

Fig. 8. Dendrogram showing molecular relationship between the four ECM strains (F8, F9, F10 and F11) based on ISSR analysis using Dice Measure
Data also showed that, there were no differences in root length between treated and untreated but there were clear differences in shoot length plants with the same treatment. On the other hand, Pinus seedling inoculated with ECM strains increased the root and shoot dry weight compared with uninoculated treatment (control).

Data of NPK uptake of Pinus seedling inoculated with ECM isolates and uninoculated were recorded in Table (7). Results showed that, inoculation with ECM strains increased the NPK uptake in root and shoot compared with the uninoculated plants (control).The highest records of $\mathrm{N}$ and $\mathrm{K}$ uptake were obtained from strain F8 being, 0.6, 0.1 and $1.19,0.18 \mathrm{gm} /$ plant of shoot and root, respectively but $\mathrm{P}$ uptake of the shoot and root obtained being 0.02 and 0.12 respectively.

\section{DISCUSSION}

Ectomycorrhizal (ECM) fungi are functionally important in forest ecosystem for plant nutrient and water uptake as well as protection from root pathogens (Smith \& Read, 1997).

EMC fungi are usually isolated from fruiting bodies, sexually spores, rhizomorphs, mycelial cords, sclerotia and ECM sheath (True \& Agerer, 1990). Members of Boletaceae, Cortinariaceae, Amanitaceae, and Cortinariaceae see Table (1); have been cited as ectomycorrhizal with Pinus and other conifers (Malajczuk et al 1982). All genera are considered to be mainly associated with adult trees (Fleming et al 1986 and Mason et al 1983). Differences in root colonization capacity and different mycorrhizal dichotomous roots were detected among fungal isolates (Pera\& Alvares 1995).

Inoculation of Pinus seedling with ECM isolates $(\mathrm{F} 8, \mathrm{~F} 9, \mathrm{~F} 10$ and F11) were associated with increased growth parameters (root, shoot length and root shoot dry weight) and nutrient uptake (NPK) compared with control. The enhancement of Pinus seedlings growth and nutrient uptake could be attributed to the ability of the ectomycorrhizal fungi to produce plant- growth promoting factors that affect the root and shoot growth and branching. The same trend of results was also reported by (Le Tacon et al 1992; Villeneuve et al 1991; Tonkin et al 1989; Castellano \& Trappe 1985 and Stenstrom et al 1985). 
Table 6. Effect of inoculation with four Ectomycorrhizal strains on growth parameters of Pinus seedlings

\begin{tabular}{|cccccc|}
\hline $\begin{array}{c}\text { ECM } \\
\text { strains }\end{array}$ & $\begin{array}{c}\text { Number of } \\
\text { Mycorrhizal } \\
\text { dichotomous } \\
\text { roots/plant }\end{array}$ & $\begin{array}{c}\text { Shoot } \\
\text { length } \\
(\mathrm{cm} / \text { plant })\end{array}$ & $\begin{array}{c}\text { Root } \\
\text { length } \\
(\mathrm{cm} / \text { plant })\end{array}$ & $\begin{array}{c}\text { Root dry weight } \\
(\mathrm{gm} / \text { plant })\end{array}$ & $\begin{array}{c}\text { Shoot dry weight } \\
\text { (gm/ plant })\end{array}$ \\
\hline F8 & 26.00 & 13.00 & 33.20 & 0.45 & 0.69 \\
F9 & 37.50 & 10.50 & 34.17 & 0.26 & 0.33 \\
F10 & 64.17 & 11.17 & 33.50 & 0.27 & 0.2 \\
F11 & 43.00 & 10.80 & 34.00 & 0.17 & 0.35 \\
\hline Control & - & 8.67 & 33.00 & 0.12 & 0.15 \\
\hline
\end{tabular}

Table 7. Effect of inoculation with four ectomycorrhizal strains on $\mathrm{N} \& \mathrm{P} \& \mathrm{~K}$ uptake of Pinus seedling

\begin{tabular}{|ccccccc|}
\hline \multirow{2}{*}{ ECM Strains } & \multicolumn{3}{c}{ Root } & \multicolumn{4}{c|}{ Shoot } \\
\cline { 2 - 7 } & $\mathrm{N}$ & $\mathrm{P}$ & $\mathrm{K}$ & $\mathrm{N}$ & $\mathrm{P}$ & $\mathrm{K}$ \\
\hline F8 & 0.61 & 0.02 & 0.18 & 1.19 & 0.12 & 0.18 \\
F9 & 0.36 & 0.02 & 0.10 & 0.66 & 0.04 & 0.18 \\
F10 & 0.24 & 0.02 & 0.06 & 0.39 & 0.02 & 0.09 \\
F11 & 0.17 & 0.02 & 0.05 & 0.88 & 0.08 & 0.09 \\
\hline control & 0.08 & 0.01 & 0.04 & 0.16 & 0.02 & 0.07 \\
\hline
\end{tabular}

\section{REFERENCES}

Allen, E.B.; M.F. Allen; D.J. Helm; J.M. Trappe; R.M. Molina and E. Rinacon, (1995). Patterns and regulation of Mycorrhizal plant and fungal diversty. Plant and Soil. 170: 47-62.

Agerer, R. (1991). Characterization of ectomycorrhiza. In: Methods in Microbiology. Vol.23. pp. 25-73. Norris, .J.R.;D.J. Read and A.K. Varma(eds). Academic Press, New York.

Brundrett, M.; N. Bougher; B. Dell; T. Grove; and N. Malajczuk , (1996). Working with Mycorrhizas in Forestry and Agriculture. pp 495. Lynch, P. (ed), Pirie Printers, Canberra, Australia. Burgess, T.; B. Dell, and N. Malajczuk, (1994). Variation in mycorrhizal development and growth stimulation by 20 Pisolithus isolates inoculated on to Eucalyptus grandis. New Phytol. 127: 731739.
Castellano, M.A. and J.M. Trappe, (1985). Mycorrhizal associations of five species of Monotropoideae in Oregen. Mycologia 7: 499-502.

Fleming, L.V.; J.W. Deacon, and F.T. Last, (1986). Ectomycorrhizal succession in a Scottish brich wood. In: Mycorrhizal Physiology and Genetics. pp. 259-264. Gianinazzi- Pearson, V. and S. Gianinazzi, (eds) INRA. Paris..

Hutchinson, L.J. (1991). Description and identification of cultures of ectomycorrhizal fungi found in North America. Mycotaxon 42: 387-504.

Jackson, M.L. (1973). Soil Chemical Analysis. pp. 183 -192. Prentice Hall of India Private Limited, New Delhi, India.

Jin, J.; Y.K. Lee and B.L. Wickes, (2004). Simple Chemical Extraction Method for DNA Isolation from Aspergillus fumigatus and other Aspergillus Species. Journal of Clinical Microbiology. 42 (9): 4293 - 4296. 
Le Tacon, F.; I.F. Alvarez; D. Bouchard; B. Henrion; R.M. Jackson; S. Luff ; J. Parladé; J. Pera; E. Stenström; N. Villeneuve and C. Walker, (1992). Variation in field response of forest trees to nursery ectomycorrhizal inoculation in Europe. In: Mycorrhizas in Ecosystems. pp. 119-134. Read,D. J. and D.H. Lewis; A.H.Fitter and I.J. Alexander (eds). CAB, Wallingford, UK.

Malajczuk, N.; R. Molina, and J.M. Trappe, (1982). Ectomycorrhiza formation in Eucalyptus. I. Pure culture synthesis, host specificity and mycorrhizal competapility in Pinus radiate. New Phytol. 91: 467-482.

Marx, D.H. (1969). The influence of ectotrophic Mycorrhizal fungi on the resistance of pine roots to pathogenic infection. I. Antagonism of Mycorrhizal fungi to root pathogenic fungi and soil bacteria. Phytopathol. 59: 153-163.

Marx, D.H. (1980). Ectomycorrhiza fungus inoculation: a tool for improving forestation practices. In: Tropical Mycorrhiza Research. pp. 13-71. Nikola, P.(eds.).Oxford Univ. Press, London.

Mason, P.A.; J. Wilson, and F.T. Last, (1983). The concept of succession in relation to the spread of sheathing mycorrhizal fungi in inoculated tree seedlings geowing in unsterile soils. Plant and Soil. 71: 247-256.

Molina, R.; H. Massicotte and J.M. Trappe, (1992). Specificity phenomena in mycorrhizal symbiosis, community ecological consequences and practical implication. In: Mycorrhizal Functioning, and Integrative Plant Fungal Process. pp. 357-423. Allen, M.F. (eds). Chapman \& Hall, New York.
Pera, J. and I.F. Alvarez, (1995). Ectomycorrhizal fungi of Pinus pinaster. Mycorrhiza 5: 193200.

Perry, D.A.; R. Molina; M.P. Amaranthus, (1995). Mycorrhizae, mycorrhizospheres and reforestation: current knowledge and research needs. Can. J. For. Res. 17: 929-940.

Read, D.J. (1991). Mycorrhizas in ecosystem. Experientia. 47:376-391.

Smith, S.E. and D.J. Read, (1997). Mycorrhizal Symbiosis. pp. 161-290. Academic Press, London,United Kingdom.

Stenström, E.; M. Ek and T. Unestam, (1985). Prolonged effects of initially introduced mycorrhizae of pine plants after outplanting. In: Mycorrhizal Physiology and Genetics. pp. 503-506. Gianinazzi- pearson, V. and S. Gianinazzi, (eds), INRA. Paris.

Tonkin, C.M.; N. Malajczuk, and J.A. McCmb, (1989). Ectomycorrhizal formation by micropropagated clones of Eucalyptus marginata inoculated with isolates of Pisolithus tinctorius. New Phytol. 111: 209-214.

True, R. and R. Agerer, (1990). Culture characteristics of some Mycena species. Mycotaxon 38: 279-309.

Villeneuve, N.; F. Le-Tacon, and D. Bouchard, (1991). Survival of inoculated Laccaria bicolor in competition with native ectomycorrhizal fungi and effects on the growth of outplanted Douglas- fir seedlings. Plant and Soil 135: 95-107.

Zhou, S.; R. D.R. Smith, and G.R. Stanosz, (2001). Differentiation of Botryosphaeria species and related anamorphic fungi using Inter Simple or Short Sequence Repeat (ISSR) fingerprinting. Mycol. Res. 105(8): 919-926. 